Sains Malaysiana 49(7)(2020): 1713-1718

http://dx.doi.org/10.17576/jsm-2020-4907-21

\title{
Role of Serum Asymmetric Dimethylarginine Level in Cardiovascular Diseases Early Prognostic in Patients with Obstructive Sleep Apnea-Hypopnea Syndrome (Peranan Tahap Serum Asimetri Dimetilarginina pada Pesakit Prognostik Awal Penyakit Kardiovaskular dengan Sindrom Apnea-Hipopnea Tidur Obstruktif)
}

\author{
JiNPING WANG*, LIJIE YUAN, HAIXIANG ZHANG \& YONGGANG YUN
}

\begin{abstract}
The purpose of this paper was to investigate the role of serum asymmetric dimethylarginine (ADMA) in patients with obstructive sleep apnea-hypopnea syndrome (OSAHS) and identify its clinical significance in OSAHS related cardiovascular diseases. A total of 75 patients with OSAHS were enrolled and divided into mild $(n=25)$, moderate $(n=27)$, and severe group $(n=23)$ according to their apnea hypopnea index (AHI) and minimal oxygen saturation $\left(\mathrm{SaO}_{2}\right.$ min $)$, respectively. Thirty healthy individuals were enrolled as normal control. Serum ADMA was measured with enzyme-linked immunosorbent assay (ELISA). Nitric oxide (NO) level was assayed with colorimetric method. Nasal continuous positive airway pressure (nCPAP) treatment was performed to the patients, and the follow up lasted for 2 months. Serum ADMA level increased with the severity of patients. Serum NO level decreased with severity of patients. A negative correlation was noticed between serum $\mathrm{NO}$ and mean $\mathrm{SaO}_{2}\left(\mathrm{SaO}_{2}\right.$ mean $)$ and minimal $\mathrm{SaO}_{2}\left(\mathrm{SaO}_{2}\right.$ min $)$. Serum ADMA was positively correlated with $A H I, t_{\mathrm{SaO}_{2}<90 \%}$ and morbidity of cardiovascular diseases. After $n C P A P$ therapy, the serum ADMA level was remarkably decreased and NO was remarkably increased in patients with OSAHS. Serum ADMA may be correlated with OSAHS and OSAHS related cardiovascular diseases. Reducing the plasma ADMA level by $n C P A P$ therapy can reduce the morbidity of OSAHS-related cardiovascular diseases.
\end{abstract}

Keywords: Asymmetric dimethylarginine; nasal continuous positive airway pressure; nitric oxide; obstructive sleep apnea-hypopnea syndrome; $\mathrm{SaO}_{2}$

\section{ABSTRAK}

Kajian ini dijalankan untuk mengkaji peranan serum asimetri dimetilarginin (ADMA) pada pesakit dengan sindrom apnea-hipopnea tidur obstruktif (OSAHS) dan mengenal pasti keertian klinikal dalam penyakit kardiovaskular yang berkaitan dengan OSAHS. Seramai 75 pesakit OSAHS telah didaftarkan dan dibahagikan kepada kumpulan ringan $(n=25)$, sederhana $(n=27)$ dan kumpulan teruk $(n=23)$ mengikut indeks apnea hipopnea (AHI) dan ketepuan oksigen minimum ( $\mathrm{SaO}_{2 \text { min }}$ ), masing-masing. Tiga puluh individu yang sihat didaftarkan sebagai kawalan normal. Serum ADMA diukur dengan asai imunoserapan terangkai enzim (ELISA). Tahap oksida nitrat (NO) diuji dengan kaedah kolorimetri. Rawatan tekanan salur udara positif berterusan nasal (nCPAP) dijalankan pada pesakit, dan disusulkan berlangsung selama 2 bulan. Tahap ADMA serum meningkat dengan tahap keterukan pesakit. Tahap NO serum menurun dengan tahap keterukan pesakit. Hubungan negatif diperhatikan antara serum $\mathrm{NO}$ dan min $\mathrm{SaO}_{2}\left(\mathrm{SaO}_{2}\right.$ mean $)$ dan minimum $\mathrm{SaO}_{2}\left(\mathrm{SaO}_{2 \text { min }}\right)$. Serum ADMA berkorelasi positif dengan AHI, $t_{\mathrm{SaO} 2<90 \%}$, dan morbiditi penyakit kardiovaskular. Selepas terapi nCPAP, tahap ADMA serum menurun dan NO meningkat pada pesakit dengan OSAHS. ADMA serum mungkin berkorelasi dengan penyakit kardiovaskular yang berkaitan dengan OSAHS dan OSAHS. Pengurangan tahap ADMA plasma dengan terapi $n$ CPAP dapat mengurangkan tahap penyakit kardiovaskular yang berkaitan dengan OSAHS.

Kata kunci: Asimetri dimetilarginina; nitrik oksida; $\mathrm{SaO}_{2}$; sindrom apnea-hipopnea tidur obstruktif; tekanan salur udara positif berterusan nasal

\section{INTRODUCTION}

Obstructive sleep apnea-hypopnea syndrome (OSAHS) refers to repetitive episodes of airflow reduction and/ or cessation due to upper airway collapse during sleep (Friedman et al. 2005). The typical feature of OSAHS is reiterative occurrence of upper airway obstruction during sleep, and on some occasions, patients may present snoring, breath holding, headache and dizzy on morning, as well as daytime sleepiness and acratia (De Backer 2013). Extensive evidence indicated that OSAHS is independently 
associated with increased risk of myocardial infarction, stroke, and mortality from cardiovascular diseases (Drager et al. 2011; Monahan \& Redline 2011; Schafer et al. 1999). To date, the exact epidemiological reasons for the cardiovascular death have not been well defined. Although several mechanisms are involved, accelerated progression of atherosclerosis may be reasonable to explain the link between OSAHS and the death (Turmel et al. 2009).

Oxidative stress has been considered to be independently associated with the severity of OSAHS (Yamauchi et al. 2005). Schulz et al. (2000) reported the oxidative stress in patients with untreated OSAHS was increased. In addition, Barcelo et al. (2000) demonstrated an increase of plasma lipid peroxides in these patients. Further, patients with OSAHS showed a reduced antioxidant capacity compared with the healthy individuals. Asymmetric dimethylarginine (ADMA), an endogenous inhibitor of nitric oxide synthase, could reduce the production of nitric oxide (NO) in vivo and consequently resulting in endothelial dysfunction and cardiovascular disorders (Colonna et al. 2009). Plasma ADMA, acted as one of the typical characteristics for patients with endothelial function disorder, increased with severity of endothelial function disproportion (Sibal et al. 2011). Thus, it could be used as a predictor of the occurrence, development and prognosis for the cardiovascular diseases. In this study, we investigated the changes of plasma ADMA in patients with OSAHS, and its correlation with the cardiovascular diseases. Our results indicated reducing the plasma ADMA level by nCPAP therapy can reduce the morbidity of OSAHS-related cardiovascular diseases.

\section{MATERIALS AND METHODS}

\section{PATIENTS}

A total of 75 patients diagnosed with OSAHS by PSG in our department from Jan 2011 to Dec 2012 were selected as study subjects, including 55 males and 20 females, aged from 32 to 76 years, with an average age of $(48.67 \pm 13.83)$ years and a body mass index (BMI) of $(33.51 \pm 4.38) \mathrm{kg} / \mathrm{m}^{2}$. The diagnosis of the patients was consistent with the guidelines for OSAHS developed by Sleep Respiratory Diseases Group, Chinese Respiratory Association (Monahan \& Redline 2011), never accepted any treatment for OSAHS. According to apnea hypoventilation index (AHI), the lowest oxygen saturation $\left(\mathrm{SaO}_{2 \text { min }}\right)$ patients can be divided into mild group (25 cases), moderate group (27 cases) and severe group ( 23 cases). The control group was divided into 30 healthy subjects with the same age and BMI, including 22 males and 8 females, aged from 36 to 73 years, with an average age of $(47.32 \pm 10.47)$ years and BMI $(35.47 \pm 3.78) \mathrm{kg} / \mathrm{m}^{2}$. All the control subjects are ruled out neuromuscular disorder, infectious diseases, chronic respiratory diseases, rheumatic autoimmune disease, tumor, peripheral vascular disease, blood coagulation dysfunction, kidney disease, coronary heart disease, heart disease, and nearly 3 months there is no history of trauma, surgery, no application hormone and immune inhibitors and free radical scavenger. Cardiovascular and cerebrovascular diseases mainly refer to coronary heart disease and cerebral apoplexy, which meet the diagnostic criteria for ischemic heart disease formulated by the International Society of Cardiology and the World Health Organization and the diagnostic criteria for various cerebrovascular diseases formulated by the Chinese Society of Neurology and Neurosurgery respectively (Turmel et al. 2009; Yamauchi et al. 2005). This study was approved by the Ethic Committee of Shaanxi Provincial People's Hospital, and written informed consents were obtained from each patient.

In the relation between 50 patients, randomly selected 34 patients with nasal continuous positive airway pressure (nCPAP) patients, as treatment group; 16 patients who did not receive any OSAHS treatment were randomly selected as the control group. They were followed up for 2 months, during which they were not allowed to accept any treatment measures against OSAHS, including hypotensive treatment, hypoglycemic treatment and other measures.

\section{MONITORING OF PSG PARAMETERS}

The patients were not allowed to take medications that may affect the sleep, respiration and heart rates $24 \mathrm{~h}$ before the monitoring. In addition, heavy exercises were forbidden. The PSG was monitored using Polysmith system (Neurotronics, Gainesville, FL, USA), including AHI, mean blood oxygen saturation $\left(\mathrm{SaO}_{2 \text { mean }}\right)$, minimal blood oxygen saturation $\left(\mathrm{SaO}_{2 \text { min }}\right)$, and $t_{\mathrm{SaO} 2<90 \%}$.

\section{SAMPLE COLLECTION}

Venous blood $(5 \mathrm{~mL})$ was collected from each subject on the morning after PSG. Blood pressure was evaluated using a pneumoelectric micro-processor-controlled facility and was recorded by a qualified medical staff. The samples were centrifuged at $3000 \mathrm{rpm}$ for $15 \mathrm{~min}$. Serum ADMA was performed using enzyme-linked immunosorbent assay (ELISA). Concentration of NO was determined using the Nitric oxide assay kit (A0131) purchased from Jiancheng Biotechnology (Nanjing, China) according to the manufacturer's instructions.

\section{DIAGNOSIS OF CARDIOVASCULAR DISEASES}

Diagnosis of the cardiovascular diseases was performed using the routine electrocardiogram, $24 \mathrm{~h}$ dynamic blood pressure, electrocardiogram, and cardiac ultrasound, cranial CT scan or MRI. The major cardiovascular diseases diagnosed in this study included hypertension, angina pectoris, myocardial infarction, ischemic cardiomyopathy, silent myocardial ischemia, cerebral 
hemorrhage, cerebral infarction, and transient ischemic attack.

\section{TREATMENT}

All the patients underwent nCPAP therapy received pressure titration that was suitable to eliminate the apnea. Meanwhile, $\mathrm{SaO}_{2}$ was monitored. The final pressure was maintained at a pressure that could eliminate the snoring and apnea, as well as a $\mathrm{SaO}_{2}$ of more than $90 \%$.

\section{FOLLOW UP}

Follow up was performed using telephone communication at week 1, 2, and 4 after discharge. The patients were required to visit the outpatient department in our hospital for the recheck, including the ADMA, NO and the onset of cardiovascular diseases

\section{STATISTICAL ANALYSIS}

SPSS20.0 software was used for the data analysis. All the measurement data were presented as mean \pm standard deviation. Analysis of variance was performed for the inter-group comparison. Student's t test was conducted to compare the data before and after treatment. Spearman correlation analysis was performed to identify the correlation of ADMA level and NO, as well as the onset of cardiovascular diseases, $P<0.05$ demonstrated statistical difference.

\section{RESULTS}

\section{PATIENT CHARACTERISTICS}

A total of 75 patients (55 men and 20 women) were enrolled in the OSAHS group, while the number of healthy individuals enrolled was 30 (22 male and 8 female). The OSAHS patients were at a range of 32 years to 76 years $(48.67 \pm 13.83)$. Body mass index (BMI) was $33.51 \pm 4.38 \mathrm{~kg} / \mathrm{m}^{2}$. For the control group, the age was 36 years to 73 years $(47.32 \pm 10.47)$, and the BMI was $35.47 \pm 3.78 \mathrm{~kg} / \mathrm{m}^{2}$. No statistical difference was noticed in the age and BMI of the OSAHS patients compared with that of control group.

\section{PSG PARAMETERS}

No statistical significance was noticed in the age, sex ratio, and BMI in the OSAHS groups compared with those of the control group $(P>0.05)$. PSG parameters, including AHI, $\mathrm{SaO}_{2 \text { mean }}, \mathrm{SaO}_{2 \text { min }}$, and $t_{\mathrm{SaO}<<90 \%}$ were determined in this study. As shown in Table 1 , the level of $\mathrm{AHI}, \mathrm{SaO}_{2 \text { mean }}$ and $\mathrm{SaO}_{2 \text { min }}$ showed remarkable decrease in the OSAHS patients compared with the control group. Nevertheless, the level of $t_{\mathrm{SaO}<90 \%}$ was remarkably increased compared with the control group. Serum ADMA level and serum $\mathrm{NO}$, as well as the morbidity of cardiovascular diseases compared with the control group, the level of serum ADMA was remarkably increased in the OSAHS patients (Table 1). For the serum NO, significant decrease was noticed in the OSAHS patients compared with the control group. The morbidity of cardiovascular diseases increased was higher in the OSAHS patients compared with that of control group. Spearman rank analysis demonstrated serum ADMA was negatively correlated with NO $(\mathrm{r}=-0.47, P<0.01)$. AHI and $t_{\mathrm{SpO} 2<90 \%}$ were positively correlated with serum ADMA $(\mathrm{r}=0.65, P<0.01$; $\mathrm{r}=0.76, P<0.01)$. In addition, AHI and $t_{\mathrm{SpO} 2<90 \%}$ were negatively correlation with serum NO level $(\mathrm{r}=-0.49$, $P<0.01 ; \mathrm{r}=-0.63, P<0.01)$. Further, $\mathrm{SaO}_{2 \text { mean }}$ and $\mathrm{SaO}_{2 \text { min }}$, were negatively correlated with serum ADMA $(\mathrm{r}=-0.37$, $P<0.01 ; \mathrm{r}=-0.48, P<0.01)$, and positively correlated with serum NO (r=0.78, $P<0.01 ; \mathrm{r}=0.84, P<0.01)$.

\section{PSG PARAMETERS AFTER NCPAP INTERFERENCE}

Among the 50 OSAHS patients, 34 patients received nCPAP treatment and the other 16 patients from the middle and sever group received no treatment were followed for 2 months. No statistical significance was noticed at the terms of age, sex ratio and BMI in the nCPAP and control group. For the PSG parameters, no significant difference was noticed in the AHI, $\mathrm{SaO}_{2}$ mean, $\mathrm{SaO}_{2 \min }, t_{\mathrm{SaO} 2<90 \%}$ in the control group at 2 months compared with the baseline levels. Nevertheless, in the nCPAP group, statistical difference was identified in these parameters at 2 months compared with the baseline levels.

TABLE 1. Comparison of PSG parameters, serum ADMA, NO levels and incidence of cardiovascular and cerebrovascular diseases between OSAHS groups and control groups

\begin{tabular}{|c|c|c|c|c|c|c|c|}
\hline Group & $\mathrm{N}$ & $\begin{array}{c}\mathrm{SaO}_{2 \text { mean }} \\
(\%)\end{array}$ & $\begin{array}{c}\mathrm{SaO}_{2 \min } \\
(\%)\end{array}$ & $\begin{array}{c}t_{\mathrm{SaO} 2<90 \%} \\
(\mathrm{~min})\end{array}$ & $\begin{array}{c}\rho_{\mathrm{ADMA}} \\
(\mu \mathrm{mol} / \mathrm{L})\end{array}$ & $\begin{array}{c}\rho_{\mathrm{NO}} \\
(\mu \mathrm{mol} / \mathrm{L})\end{array}$ & $\begin{array}{c}\text { morbidity } \\
(\%)\end{array}$ \\
\hline Control & 30 & $94.37 \pm 1.76$ & $89.24 \pm 0.65$ & $3.89 \pm 0.78$ & $2.41 \pm 0.59$ & $54.03 \pm 5.76$ & 6.67 \\
\hline Mild group & 25 & $93.15 \pm 1.68^{*}$ & $85.55 \pm 0.49 *$ & $50.26 \pm 10.35^{*}$ & $3.35 \pm 0.46^{*}$ & $47.39 \pm 3.44^{*}$ & $28.00 *$ \\
\hline Moderate group & 27 & $90.57 \pm 1.73 * * \Delta$ & $80.38 \pm 0.77 * * \mathbf{\Lambda}$ & $97.46 \pm 16.95 * * \boldsymbol{\Delta}$ & $4.28 \pm 0.62 * * \boldsymbol{\Lambda}$ & $38.19 \pm 4.86^{* * \boldsymbol{\Lambda}}$ & $40.74 * * \Lambda$ \\
\hline Severe group & 23 & $87.39 \pm 1.49 * * \Delta$ ム\# & $75.87 \pm 0.56 * * \Delta$ ム\# & $143.14 \pm 20.49 * * \boldsymbol{\Lambda}$ ム\# & $5.17 \pm 0.51 * * \Delta$ А\# & $25.75 \pm 2.57 * * \Delta \Delta \#$ & $52.17 * * \Delta$ ム\# \\
\hline$F$ value & & 15.23 & 17.21 & 19.03 & 16.32 & 15.96 & 11.24 \\
\hline$P$ value & & $<0.01$ & $<0.01$ & $<0.01$ & $<0.01$ & $<0.01$ & $<0.01$ \\
\hline
\end{tabular}


TABLE 2. Comparison of PSG parameters, serum ADMA and NO levels before and after nCPAP treatment

\begin{tabular}{|c|c|c|c|c|c|c|c|c|}
\hline \multicolumn{2}{|c|}{ Group } & $\mathrm{N}$ & AHI & $\mathrm{SaO}_{2 \text { mean }}$ & $\mathrm{SaO}_{2 \text { min }}$ & $t_{\mathrm{SaO} 2<90 \%}$ & $\rho_{\mathrm{ADMA}}$ & $\rho_{\mathrm{NO}}$ \\
\hline Control & Baseline & 16 & $35.87 \pm 10.33$ & $89.37 \pm 1.58$ & $78.84 \pm 1.96$ & $115.74 \pm 18.48$ & $4.76 \pm 0.65$ & $30.06 \pm 3.18$ \\
\hline group & 2 months & 16 & $33.23 \pm 10.05$ & $91.52 \pm 1.93$ & $80.59 \pm 1.44$ & $104.05 \pm 15.05$ & $5.10 \pm 0.71$ & $28.79 \pm 2.83$ \\
\hline nCPAP & Baseline & 34 & $34.75 \pm 12.16$ & $90.56 \pm 1.57$ & $79.35 \pm 1.70$ & $113.61 \pm 17.46$ & $6.12 \pm 075$ & $31.79 \pm 3.41$ \\
\hline group & 2 months & 34 & $4.46 \pm 0.92 * \Delta$ & $94.17 \pm 2.14^{* \boldsymbol{\Delta}}$ & $89.36 \pm 1.56 * \Delta$ & $8.92 \pm 1.01 * \Delta$ & $2.89 \pm 0.38 * \boldsymbol{\Delta}$ & $50.15 \pm 6.02 * \Delta$ \\
\hline
\end{tabular}

* $P<0.01$, compared with the 2-month parameters of the control group; $\triangle P<0.01$, compared with the baseline level of the nCPAP group

\section{SERUM ADMA LEVEL AND SERUM NO AFTER NCPAP}

For the serum ADMA and NO, no statistical difference was shown at 2 months in the control group compared with the baseline levels. After interference of nCPAP, the serum ADMA was remarkable decreased compared with the baseline level $(2.89 \pm 0.38$ vs $6.12 \pm 0.75)$. Nevertheless, the level of NO was remarkably increased after interference of nCPAP compared with the baseline value (Table 2).

\section{DISCUSSION}

In this study, we aim to investigate the changes of plasma ADMA in patients with OSAHS, and its correlation with the onset of cardiovascular diseases. Our results indicated reducing the plasma ADMA level by nCPAP therapy can reduce the morbidity of cardiovascular diseases in patients with OSAHS.

Patients with OSAHS usually present injuries to multiple organs, including heart, brain, kidney and lung, especially the cardiovascular system (Hayashi et al. 2008). The pathogenesis of OSAHS patients with cardiovascular diseases involved several mechanisms, among which atherosclerosis induced by oxidative stress and inflammation has been well acknowledged (Lavie \& Lavie 2009). For the OSAHS patients developed atherosclerosis, long-term hypoxemia and disorder of microcirculation at night may finally induce injury of endothelial cells (Lee et al. 2008).

NO, an endothelium derived relax factor, is synthesized from L-arginine via endothelial NOS, and is considered as a mediator that induces vasodilatation, and prevents adhesion of platelets to endothelial cells (Forstermann \& Munzel 2006). Thus, patients with longterm OSAHS may be influenced by NO dys-regulation. As previously described, the level of NO was lower than the normal individuals, which could be reserved by nCPAP therapy (Drager et al. 2011). In this study, the level of NO in OSAHS patients was also lower than the normal control. Meanwhile, the decrease of NO was more significant in those with severe clinical signs. After interference of nCPAP, the serum NO was elevated to the normal range, and at the same time, the $\mathrm{SaO}_{2 \text { mean }}$ and $\mathrm{SaO}_{2 \text { min }}$ were increased, demonstrating that the oxygen level in serum was increased. Taken together, NO was proved to play crucial roles in the pathogenesis of OSAHS.

ADMA, an endogenous competitive inhibitor of NOS, has been reported to be elevated in OSAHS patients (Sunnetcioglu et al. 2016). Thus, it may play important role in the inhibition of NOS activity. As previously described, the level of ADMA was up-regulated in plasma samples obtained from patients with OSAHS compared with the normal individuals (Yüksel et al. 2014). Recently, ADMA has been reported to be associated with the development of several diseases, including coronary atherosclerosis, peripheral vascular disease, type II diabetes mellitus, chronic renal failure, and hypertension (Kielstein et al. 2002; Liu et al. 2018; Perticone et al. 2005; Ueda et al. 2007). In this study, patients with severe OSAHS showed elevated ADMA level, which was positively correlated with the AHI, $t_{\mathrm{SaO}<90 \%}$, and the incidence of cardiovascular diseases. However, a negative correlation was noticed between ADMA and $\mathrm{SaO}_{2 \text { mean }}$ and $\mathrm{SaO}_{2 \text { min. }}$. All these indicated that ADMA played a crucial role in the pathogenesis of OSAHS.

\section{CONCLUSION}

In conclusion, with the aggravation of OSAHS contributed to the elevation of ADMA, which resulted 
in decline of serum NOS and NO, as well as progression of cardiovascular diseases. The nCPAP could reverse the symptoms by down-regulating the serum ADMA and up-regulating NO, which finally decreased the onset of cardiovascular diseases. Therefore, we believe that the detection of serum ADMA level can be used as an early prognostic indicator for OSAHS patients, which is characterized by simple operation, low cost, accurate and sensitive results, and worthy of clinical study with larger samples. Of course, the next step is to explore the correlation between ADMA levels and OSAHS severity by adjusting a multivariate model for the severity of underlying heart failure, and to conduct an objective evaluation test for exercise intolerance during follow-up, which will make this study more convincing.

\section{ACKNOWLEDGEMENTS}

This study was supported by natural science basic research plan in Shaanxi province of China (No. 2018JM7145). We thank Yang Sun for participation in data analysis. In this work, Jinping Wang participated in research design, Lijie Yuan and Yonggang Yun participated in the performance of the research, Jinping Wang and Haixiang Zhang participated in the writing of the paper. All authors declares no conflict of interest. This article does not contain any studies with animals performed by any of the authors. Informed consent was obtained from all individual participants included in the study.

\section{REFERENCES}

Barcelo, A., Miralles, C., Barbe, F., Vila, M., Pons, S. \& Agusti, A.G. 2000. Abnormal lipid peroxidation in patients with sleep apnoea. European Respiratory Journal 16(4): 644-647.

Colonna, V.D.G., Bianchi, M., Pascale, V., Ferrario, P., Morelli, F., Pascale, W., Tomasoni, L. \& Turiel, M. 2009. Asymmetric dimethylarginine (ADMA): An endogenous inhibitor of nitric oxide synthase and a novel cardiovascular risk molecule. Medical Science Monitor 15(4): RA91-RA101.

De Backer, W. 2013. Obstructive sleep apnea/hypopnea syndrome. Panminerva Medica 55(2): 191-195.

Drager, L.F., Polotsky, V.Y. \& Lorenzi-Filho, G. 2011. Obstructive sleep apnea: An emerging risk factor for atherosclerosis. Chest 140(2): 534-542.

Forstermann, U. \& Munzel, T. 2006. Endothelial nitric oxide synthase in vascular disease: From marvel to menace. Circulation 113(13): 1708-1714.

Friedman, M., Vidyasagar, R., Bliznikas, D. \& Joseph, N. 2005. Does severity of obstructive sleep apnea/hypopnea syndrome predict uvulopalatopharyngoplasty outcome? The Laryngoscope 115(12): 2109-2113.

Hayashi, Y., Barron, G.J. \& Almeida, A.A. 2008. Operative timing for absent pulmonary valve with obstructive sleep apnea. Asian Cardiovascular and Thoracic Annals 16(6): e52-e54.
Kielstein, J.T., Böger, R.H., Bode-Böger, S.M., Frölich, J.C., Haller, H., Ritz, E. \& Fliser, D. 2002. Marked increase of asymmetric dimethylarginine in patients with incipient primary chronic renal disease. Journal of the American Society of Nephrology 13(1): 170-176.

Lavie, L. \& Lavie, P. 2009. Molecular mechanisms of cardiovascular disease in OSAHS: The oxidative stress link. European Respiratory Journal 33(6): 1467-1484.

Lee, S.A., Amis, T.C., Byth, K., Larcos, G., Kairaitis, K., Robinson, T.D. \& Wheatley, J.R. 2008. Heavy snoring as a cause of carotid artery atherosclerosis. Sleep 31(9): 12071213.

Liu, X., Xu, X., Shang, R. \& Chen, Y. 2018. Asymmetric dimethylarginine (ADMA) as an important risk factor for the increased cardiovascular diseases and heart failure in chronic kidney disease. Nitric Oxide 78: 113-120.

Monahan, K. \& Redline, S. 2011. Role of obstructive sleep apnea in cardiovascular disease. Current Opinion in Cardiology 26(6): 541-547.

Perticone, F., Sciacqua, A., Maio, R., Perticone, M., Maas, R., Boger, R.H., Tripepi, G., Sesti, G. \& Zoccali, C. 2005. Asymmetric dimethylarginine, L-arginine, and endothelial dysfunction in essential hypertension. Journal of the American College of Cardiology 46(3): 518-523.

Schäfer, H., Koehler, U., Ewig, S., Hasper, E., Tasci, S. \& Lüderitz, B. 1999. Obstructive sleep apnea as a risk marker in coronary artery disease. Cardiology 92(2): 79-84.

Schulz, R., Mahmoudi, S., Hattar, K., Sibelius, U.L.F., Olschewski, H., Mayer, K., Seeger, W. \& Grimminger, F. 2000. Enhanced release of superoxide from polymorphonuclear neutrophils in obstructive sleep apnea: Impact of continuous positive airway pressure therapy. American Journal of Respiratory and Critical Care Medicine 162(2): 566-570.

Sibal, L., Agarwal, S.C., Home, P.D. \& Boger, R.H. 2010. The role of asymmetric dimethylarginine (ADMA) in endothelial dysfunction and cardiovascular disease. Current Cardiology Reviews 6(2): 82-90.

Sunnetcioglu, A., Asker, S., Alp, H.H. \& Gunbatar, H. 2016. Increased asymmetric dimethylarginine and ischemiamodified albumin levels in obstructive sleep apnea. Respiratory Care 61(8): 1038-1043.

Turmel, J., Sériès, F., Boulet, L.P., Poirier, P., Tardif, J.C., RodésCabeau, J., Larose, É. \& Bertrand, O.F. 2009. Relationship between atherosclerosis and the sleep apnea syndrome: An intravascular ultrasound study. International Journal of Cardiology 132(2): 203-209.

Ueda, S., Yamagishi, S.I., Matsumoto, Y., Fukami, K. \& Okuda, S. 2007. Asymmetric dimethylarginine (ADMA) is a novel emerging risk factor for cardiovascular disease and the development of renal injury in chronic kidney disease. Clinical and Experimental Nephrology 11(2): 115-121.

Yamauchi, M., Nakano, H., Maekawa, J., Okamoto, Y., Ohnishi, Y., Suzuki, T. \& Kimura, H. 2005. Oxidative stress in obstructive sleep apnea. Chest 127(5): 1674-1679.

Yüksel, M., Okur, H.K., Pelin, Z. \& Öztürk, L. 2014. Arginase activity and nitric oxide levels in patients with obstructive sleep apnea syndrome. Clinics 69(4): 247-252. 
Jinping Wang* \& Yonggang Yun

Department of ENT

Shaanxi Provincial People's Hospital

Xi'an 710068

China

Lijie Yuan

Department of Medical office infection management

Shaanxi Provincial People's Hospital

Xi'an 710068

China
Haixiang Zhang

Central Laboratory of Shaanxi Provincial People's Hospital Xi'an 710068

China

*Corresponding author; email: 306070789@qq.com

Received: 24 December 2019

Accepted: 22 March 2020 